\title{
Occurrence of polygyny in Acromyrmex subterraneus molestans Santschi 1925 (Hymenoptera: Formicidae)
}

\author{
Ocorrência de poliginia em Acromyrmex subterraneus molestans Santschi 1925 \\ (Hymenoptera: Formicidae)
}

Danival José de Souza ${ }^{1}$ José Lino Neto ${ }^{2}$ Terezinha M. C. Della Lucia ${ }^{3}$ Ethel Peternelli $^{4}$

\section{- NOTA -}

\section{ABSTRACT}

Polygyny denotes the coexistence of two or more mated and fertile queens in the colony. A colony of Acromyrmex subterraneus molestans Santschi containing 14 queens was collected on campus of the Universidade Federal de Viçosa, Brazil, aiming to verify if they were all egg-layers and fertile. The volume of the fungus garden in the nest was about $500 \mathrm{ml}$ with a large number of larvae and pupae. Observation of the ovarian development and spermathecae indicates that 13 queens had copulated and ovary did not show morphological differences among them. This could indicate that polygyny is not accidental and may represent an adaptative strategy to optimize the development of the initial colony in A. subterraneus molestans.

Key words: leaf-cutting ants, adaptative strategy, evolution.

\section{RESUMO}

O termo poliginia se refere à coexistência de duas ou mais rainhas férteis na colonia. Coletou-se no campus da Universidade Federal de Viçosa uma colonia de Acromyrmex subterraneus molestans Santschi contendo 14 rainhas, com o objetivo de verificar se todas elas eram ovipositoras e férteis. $O$ volume do jardim de fungo no ninho era de $500 \mathrm{ml} \mathrm{com}$ grande número de larvas e pupas. Observações do desenvolvimento dos ovários e espermatecas indicaram que 13 rainhas tinham copulado e seus ovários não mostraram diferenças morfológicas. Isto indicaria que a poliginia não é acidental e pode representar uma estratégia adaptativa para otimizar o desenvolvimento inicial de colônias em A. subterraneus molestans.

Palavras-chave: formigas cortadeiras, estratégia adaptativa, evolução.
Many social insect species - wasps, bees, and termites - usually have just one queen (monogyny), others may have one or several (facultative polygyny), and a few may have dozens (extreme polygyny). Polygyny - the coexistence of more than one fertile queen in the same colony - is not a very rare event in social Hymenoptera, although it is rather uncommon among leaf-cutting ants (Attini) (DELLA LUCIA \& VILELA, 1986). There are some reports on polygyny in the genus Acromyrmex Mayr 1865. In Brazil polygyny was reported by DELLA LUCIA \& VILELA (1986) in $\boldsymbol{A}$. subterraneus subterraneus. Later, DELABIE (1989) registered its occurrence in another subspecies, $\boldsymbol{A}$. subterraneus brunneus. In the United States, polygyny was extensively studied in $A$. versicolor, a species that inhabits the desert of Arizona (RISSING et al., 1986). The status of females found in a colony extremely polygynic of A. subterraneus molestans was studied in the present work, being the first report of polygyny in this subspecies.

On April 26, 2002 a colony of Acromyrmex subterraneus molestans Santschi 1925 containing 14 queens was collected in the campus of the Universidade Federal de Viçosa, Viçosa, Minas Gerais State, Brazil (20 44"s latitude; $4254 \mathrm{w}$ longitude; $639 \mathrm{~m}$ altitude). The volume of the fungus garden in the nest was about $500 \mathrm{ml}$ and there was a high number of larvae and pupae (250 approx. ).

${ }^{1}$ Biólogo, Mestre em Entomologia, Departamento de Biologia Geral, Universidade Federal de Viçosa (UFV).

${ }^{2}$ Biólogo, Doutor, Professor Adjunto, Departamento de Biologia Geral, UFV.

${ }^{3}$ Biólogo, Doutor, Professor Titular, Departamento de Biologia Animal, UFV, Av. Ph Rolfs s/n, 36570-000, Viçosa, MG. E-mail: tdlucia@mail.ufv.br. Autor para correspondência.

${ }^{4}$ Biólogo, Doutorando em Entomologia, Departamento de Biologia Animal, UFV. 
After weighing all queens (Table 1), they were individually placed in plastic pots covered with perforated lids and with a wet cotton swab on top of the lids. A cotton piece previously immersed in a 1:1 honey-water solution was followed with the purpose of evaluating egg-laying ratio. Seventy-two hours later it was verified that six of the fourteen queens had laid eggs all of which were considered viable as in MARINHO \& DELLA LUCIA (1998) (Table 1). It was hypothesized that the presence of all these queens might be due to the several a late females not leaving the mother colony during the nuptial flight. In laboratory conditions and after alate production it is common to observe virgin queens undergoing dealation and staying within the colony. In order to test whether this hypothesis was correct or if the nest was founded by this great number of queens, their spermathecae were studied. After dissection, we observed that 13 queens had completely filled spermathecae and that their spermatozoa exhibited intense movement when analyzed under a light microscope; the lack of spermatozoa was observed in only one queen, although she had laid an egg. This indicates that 13 queens had copulated and this strongly indicates that this nest was indeed founded by all these queens.

The ovaries practically did not show morphological differences among the queens. All

Table 1 - Weight, oviposition occurrence and number of viable eggs in Acromyrmex subterraneus molestans queens from a polygynic colony. Viçosa, MG. 2002.

\begin{tabular}{lccc}
\hline Queen & Weight (mg) & Oviposition & $\begin{array}{c}\text { Number of } \\
\text { eggs after 72 } \\
\text { hours }\end{array}$ \\
\hline 1 & 31.1 & occurrence & x \\
2 & 34.8 & x & 1 \\
3 & 35.0 & & \\
4 & 36.3 & x & 4 \\
5 & 34.6 & & \\
6 & 29.6 & $\mathrm{x}$ & 2 \\
7 & 38.6 & & \\
8 & 36.8 & & \\
9 & 35.5 & & \\
10 & 29.9 & & \\
11 & 36.1 & & \\
12 & 41.2 & & \\
13 & 32.5 & & \\
14 & 34.2 & & \\
Average & $34.73 \pm 3.21$ & & \\
\hline
\end{tabular}

ovarioles were well developed, having oocytes in all of the different maturation stages. In one of the queens, the ovaries were apparently more developed. The fact that eight queens did not lay any eggs does not necessarily mean that they would never do so. It was reported that egg laying in A. subterraneus subterraneus, in A. subterraneus molestans and in A. crasssispinus occurred in pulses - or at intervals (MARINHO \& DELLA LUCIA 1998). Therefore, in the present study the observations (72 hours after nest removal to the laboratory) could well be representing an interval between these pulses. Queens had different rates of egg-laying (Table 1). It is possible that some are contributing with more offsprings to the colony than the others.

More than one queen only in recently founded colonies was verified in the ant subspecies A. subterraneus brunneus (DELABIE, 1989). According to the autor, this suggests that this subspecies could have facultative polygyny. This means that at the beginning of colony formation it would be polygynic and progressively would become monogynic as the colony would age. Our colony was very small (500 $\mathrm{ml}$ of fungus garden) and probably young. Maybe some queens would be progressively eliminated. The maximum number of queens per colony of A. subterraneus brunneus obtained by DELABIE (1989) was seven. Surprisingly, in $\boldsymbol{A}$. subterraneus molestans a queen number twice as large was found. This shows that the number of queens in Acromyrmex colonies is highly variable and understanding the causes of this variation becomes a challenge for the biologists.

Recently A. subterraneus molestans has been colonizing urban areas in Brazil (DELLA LUCIA, 1993). In the same location where the colony with 14 queens was collected several other polygynic colonies have been collected; some with as much as six queens but none with 14 . This could indicate that polygyny in A. subterraneus molestans is not accidental. Polygyny may represent an adaptative strategy to optimize the development of the initial colony in this subspecies if ecological pressures are indeed a key factor in polygyny determination (KELLER, 1995).

\section{REFERENCES}

DELABIE, J.H.C. Observações sobre a ocorrência de poliginia em colônias de Acromyrmex subterraneus brunneus Forel, 1893, em cacauais. Anais da Sociedade Entomológica do Brasil, v.8, p.193-196, 1989. 
DELLA LUCIA, T.M.C.;VILELA, E.F. Ocorrência de poliginia em Acromyrmex subterraneus Fore1, 1893. Anais da Sociedade Entomológica do Brasil, v.15, p.379-380, 1986.

DELLA LUCIA, T.M.C. As formigas cortadeiras. Viçosa: Folha de Viçosa, 1993.

KELLER, L. Social life: the paradox of multiple-queens colonies. Trends in Ecology and Evolution, v.10, p.355360, 1995.
MARINHO, C.G.S.; DELLA LUCIA, T.M.C. Egg-laying in Acromyrmex spp. (Hymenoptera, Formicidae) under laboratory conditions. Biociências, v.6, p.71-79, 1998.

RISSING, S.W.; JOHNSON, R.A.; POLLOCK, G.B. Natal nest distribution and pleometrosis in the desert leaf-cutter ant Acromyrmex versicolor (Pergande) (Hymenoptera: Formicidae). Psyche, v.93, p.177186, 1986. 